JMPID ( Jurnal Manajemen Pendidikan Islam Darussalam )

Jurnal Manajemen Pendidikan Islam

Volume: 2, No: 2, September 2020

ISSN : 2722-7146 (online)

\title{
Pengaruh Manajemen Kurikulum Terhadap Prestasi Belajar Siswa Kelas XI IPA Di MA Unggulan Mamba'ul Huda Krasak Tegalsari Banyuwangi
}

\author{
Sumari Mawardi ${ }^{1}$, M. Zainul Ihsan Mustofa ${ }^{2}$ \\ e-mail : gadac163@gmail.com², ihsan.zai99@gmail.com ${ }^{2}$ \\ Prodi Manajemen Pendidikan Islam \\ Institut Agama Islam Darussalam Blokagung Banyuwangi
}

\begin{abstract}
The objectives of this research are 1). Knowing How Curriculum Management in MA Featured Mamba'ul Huda Krasak Tegalsari Banyuwangi, 2). Knowing How Students' Achievement In Ma Unggulan Mamba'ul Huda Krasak Tegalsari Banyuwangi, 3). Knowing Is There The Effect Of Curriculum Management On Students' Learning Presence in MA Unggul Mamba'ul Huda Krasak Tegalsari Banyuwangi, 4). Knowing How Much Influence Curriculum Management Has On Students' Learning Presence in MA Unggals Mamba'ul Huda Krasak Tegalsari. This type of research is descriptive quantitative by using the method of observation, interview, questionnaire, and documentation for data collection techniques while the analysis uses the correlation of Poduct Moment. The population of this research is Class XI at MA Featured Mamba'ul Huda Krasak Tegalsari as the sample Class XI IPA with 37 respondents. After conducting an analysis of his insights, it was found that the management of the curriculum at MA Unggul Huda Krasak Tegalsari was classified as good and student achievement was also classified as good. The existence of influence of curriculum management on student learning preservation at MA Featured Mamba'ul Huda Krasak Tegalsari and the influence is $77 \%$ while the rest is 23\% by other variables.
\end{abstract}

Keywords: Curriculum Management, Student Achievement

\begin{abstract}
Abstrak
Tujuan Penelitian Ini Adalah 1). Mengetahui Bagaimana Manajemen Kurikulum di MA Unggulan Mamba'ul Huda Krasak Tegalsari Banyuwangi, 2). Mengetahui Bagaimana Prestasi Belajar Siswa di MA Unggulan Mamba'ul Huda Krasak Tegalsari Banyuwangi, 3). Mengetahui Adakah Pengaruh Manajemen Kurikulum Terhadap Presatsi Belajar Siswa di MA Unggulan Mamba'ul Huda Krasak Tegalsari Banyuwangi, 4). Mengetahui Seberapa Besar Pengaruh Manajemen Kurikulum Terhadap Presatsi Belajar Siswa di MA Unggulan Mamba'ul Huda Krasak Tegalsari. Jenis Penelitian Adalah Deskriftif Kuantitatif Dengan Mengunakan Metode Observasi, Interview, Angket, dan Dokumentasi untuk Teknik Pengumpulan Data sedangkan analisisnya menggunakan Korelasi Poduct Moment. Populasi penelitian ini adalah Kelas XI di MA Unggulan Mamba'ul Huda Krasak Tegalsari sebagai sampelnya Kelas XI IPA dengan jumlah responden 37 siswa. Setelah melakukan analisis bahwasannya ditemukan hasil bahwa Manajemen Kurikulum Di MA Unggulan Mamba'ul Huda Krasak Tegalsari Tergolong Baik Dan Prestasi Belajar Siswa juga tergolong Baik. Adanya Pengauh Pengaruh Manajemen Kurikulum Terhadap Presatsi Belajar Siswa di MA Unggulan Mamba'ul Huda Krasak Tegalsari dan besar pengaruhnya sebesar $77 \%$ sedangkan sisanya sebesar $23 \%$ oleh varibel lainnya.
\end{abstract}

Kata Kunci : Manajemen Kurikulum, Prestasi Belajar Siswa

Pengaruh Manajemen Kurikulum terhadap Prestasi Belajar Siswa Kelas XI IPA di MA Unggulan Mamba'ul Huda Krasak Tegalsari Banyuwangi

Sumari Mawardi, M. Zainul Ihsan Mustofa 
JMPID ( Jurnal Manajemen Pendidikan Islam Darussalam )

Jurnal Manajemen Pendidikan Islam

Volume: 2, No: 2, September 2020

A. Pendahuluan

Pendidikan merupakan salah satu hal yang harus diperhatikan oleh kita manusia, karena dengan pendidikan manusia bisa mengasah dirinya menjadi manusia yang beradap dan berguna bagi orang banyak. Pendidikan berfungsi mengembangkan kemampuan dan bentuk watak serta peradaban bangsa yang bermartabat dalam rangka mencerdaskan kehidupan bangsa.

Kebijakan pemerintah dalam bidang pendidikan dilakukan agar pendidikan di Indonesia semakin berkembang dan maju. Kurikulum menjadi sorotan utama bagi pengembangan pendidikan di Indonesia karena kurikulum merupakan hal mendasar yang diperlukan untuk mengelola dan mengembangkan pendidikan.

Sekolah adalah salah satu pusat kegiatan belajar. Dengan demikian, sekolah merupakan tempat mengembangkan aktivitas. Aktifitas peserta didik tidak cukup hanya mendengarkan mencatat seperti yang sudah lazim terdapat di sekolah-sekolah tradisional. Proses belajar mengajar yang dilakukan oleh pendidik seharusnya diimplementasikan dengan maksimal sesuai dengan kondisi yang dialami peserta didik karena kurikulum pendidikan selalu berkembang dari masa ke masa, seperti kurikulum KTSP (kurikulum tingkat satuan pendidikan) dan sekarang menjadi kurikulum 2013.(mulyasa, 2015:59)

Kurikulum dan pembelajaran, merupakan dua hal yang tidak dapat dipisahkan. Sebagai suatu rencana atau program, kurikulum tidak akan bermakna manakala tidak diimplementasikan dalam bentuk pembelajaran. Persoalan bagaimana mengembangkan kurikulum, ternyata bukanlah hal yang mudah, serta tidak sederhana yang kita bayangkan. Dalam skala makro, kurikulum berfungsi sebagai suatu alat dan pedoman untuk mengantar peserta didik sesuai dengan harapan dan cita-cita masyarakat.(Abdul manab, 2014:116)

Dalam dunia pendidikan, istilah kurikulum ditafsirkan dalam pengertian yang berbeda-beda oleh para ahli. Kurikulum dalam dunia pendidikan seperti kata (Ronald C. Doll, 2007:8) “ Kurikulum sekolah adalah muatan proses, baik formal maupun informal yang diperuntukkan bagi pelajar untuk memperoleh pengetahuan dan pemahaman, mengembangkan keahlian dan mengubah apresiasi sikap dan nilai dengan bantuan sekolah". Sedangkan (Maurice Dulton, 2012:184) mengatakan "Kurikulum 
JMPID ( Jurnal Manajemen Pendidikan Islam Darussalam )

Jurnal Manajemen Pendidikan Islam

Volume: 2, No: 2, September 2020

dipahami sebagai pengalaman-pengalaman yang didapatkan oleh pembelajar di bawah naungan sekolah.

Dari beberapa definisi tersebut kurikulum dapat dimaknai dalam tiga konteks, yaitu sebagai sejumlah mata pelajaran yang harus ditempuh oleh peserta didik, sebagai pengalaman belajar, dan sebagai rencana program belajar. Jadi dapat disimpulkan kurikulum adalah suatu program pendidikan yang berisikan berbagai bahan ajar dan pengalaman belajar yang diprogramkan, direncanakan dan dirancangkan secara sistemik atas dasar norma-norma yang berlaku yang dijadikan pedoman dalam proses pembelajaran bagi tenaga kependidikan dan peserta didik untuk mencapai tujuan pendidikan.

Salah satu aspek yang mendasari terwujudnya keberhasilan pendidikan nasional adalah dari segi Manajemen kurikulum, manajemen kurikulum tidak akan terlepas dari kegiatan pembelajaran karena manajemen kurikulum tersebut merupakan usaha untuk mensukseskan suatu tujuan dalam pendidikan. Diperlukan adanya pengelolaan, penataan, dan pengaturan atau kegiatan yang berkaitan dengan dengan lembaga pendidikan agar dapat memenuhi tujuaan pada pendidikan tersebut secara optimal.

Manajemen kurikulum adalah segenap proses usaha bersama untuk memperlancar pencapaian tujuan pembelajaran dengan dititik beratkan pada usaha meningkatkan kualitas interaksi belajar mengajar. Manajemen Kurikulum menekankan pada suatu sistem kurikulum yang berorientasi pada produktivitas, dimana kurikulum tersebut beriorientasi pada peserta didik, kurikulum dibuat agar dapat membuat peserta didik dapat mencapai tujuan hasil belajar. (Saefullah, 2012:4)

Prestasi belajar merupakan taraf keberhasilan murid atau siswa dalam mempelajari materi pelajaran di sekolah yang dinyatakan dalam bentuk skor yang diperoleh dari hasil tes mengenai sejumlah materi pelajaran tertentu. Perubahan sebagai hasil belajar bersifat menyeluruh. bahwa perubahan sebagai hasil belajar bersifat menyeluruh baik perubahan pada perilaku maupun kepribadian secara keseluruhan. Belajar bukan semata-mata kegiatan mekanis stimulus respon, tetapi melibatkan seluruh fungsi organisme yang mempunyai tujuan-tujuan tertentu. Proses pendidikan prestasi dapat diartikan sebagai hasil dari proses belajar mengajar yakni, penguasaan, perubahan emosional, atau perubahan tingkah laku yang dapat diukur dengan tes tertentu.(Chatarina Tri Anni, 2004:9)

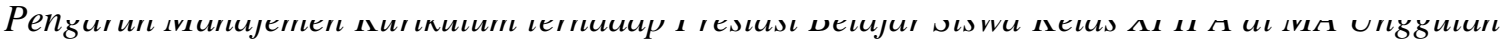
Mamba'ul Huda Krasak Tegalsari Banyuwangi

Sumari Mawardi, M. Zainul Ihsan Mustofa 
JMPID ( Jurnal Manajemen Pendidikan Islam Darussalam )

Jurnal Manajemen Pendidikan Islam

Volume: 2, No: 2, September 2020

ISSN : 2722-7146 (online)

Sebagaimana yang telah terpaparkan bahwa salah satu faktor yang mendasari prestasi belajar pesrta didik adalah pengelolaan manajemen kurikulum yang baik, jika dikaitkan pada lembaga pendidikan maka yang berperan adalah semua stakeholders terutama kepala sekolah dan guru. Setiap lembaga pendidikan tentu saja berharap dapat menjadikan peserta didik berprestasi pada setiap input, proses maupun outputnya. Sebagaimana sekolah yang lain, sekolah MA Unggulan Mamba'ul Huda Krasak Tegalsari Banyuwangi tentu juga menginginkn peserta didiknya berprestasi yang mampu menunjang perkembangan pendidikan di sekolah tersebut.

Mengenai pengembangan kurikulum dalam surah Al-Hasr ayat 18, Allah SWT berfirman :

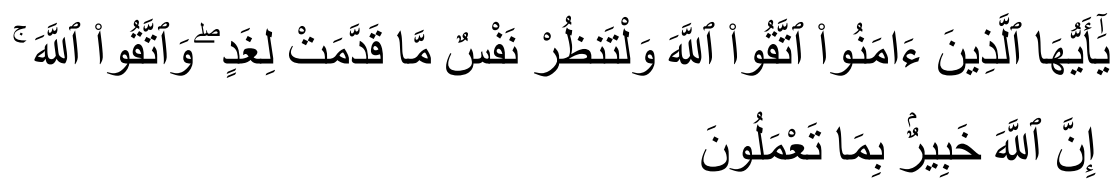

Artinya: "Hai orang-orang yang beriman, bertaqwalah kepada Allah dan hendaklah setiap diri memperhatikan apa yang telah diperbuatnya untuk hari esok (akhirat), dan bertaqwalah kepada Allah, sesungguhnya Allah maha mengetahui apa yang kamu kerjakan".

Tafsir Jalalain tentang ayat ini (Hai orang-orang yang beriman! Bertakwalah kepada Allah dan hendaklah setiap diri memperhatikan apa yang telah diperbuatnya untuk hari esok) yakni untuk menghadapi hari kiamat (dan bertakwalah kepada Allah, sesungguhnya Allah Maha Mengetahui apa yang kalian kerjakan)

Sedangkan keadaan kurikulum di MA unggulan Mamba'ul Huda masih terus menerus melakukan evaluasi dan dikembangkang agar isi dan muatannya selalu relavan dengan tuntutan masyarakat yang selalu berubah sesuai dengan perkembangan ilmu pengetahuan dan teknologi, khususnya yang berkaitan dengan disiplin ilmu tertentu serta sesuai dengan masalah yang ada pada masyarakat.

Sesuai dengan observasi awal yang dilakukan oleh peneliti di MA Unggulan Mamba'ul Huda bahwa penerapan kurikulum sekolah cukup baik dalam kenyataanya masih kurangnya fasilitas yang dibutuhkan dilihat dari berbagai kondisi yang ada sesuai dengan pernyataan kepala sekolah bahwa masih sering ditemukan masalah karena keterbatasan sarana dan prasarananya, seperti gedung, ruang kelas, 
JMPID ( Jurnal Manajemen Pendidikan Islam Darussalam )

Jurnal Manajemen Pendidikan Islam

Volume: 2, No: 2, September 2020

laboratorium, terutama tempat ibadah seperti musolah sekolah masih belum ada yang merupakan pendukung dalam proses pembelajaran.

Disinilah untuk menunjang keberhasilan kurikulum diperlukan upaya pemberdayaan bidang manajemen atau pengelolaan kurikulum. Dengan adanya perubahan kurikulum, berarti sistem yang ada dalam pelajaranpun juga berubah yang akan berdampak kepada prestasi belajar siswa.

\section{B. Rumusan Masalah}

Berdasarkan latar belakang masalah, dapat dibuat rumusan masalah, yaitu :

1. Bagaimana Manajemen kurikulum di MA Unggulan Mamba’ul Huda Krasak Tegalsari Banyuwangi?

2. Bagaimana Prestasi balajar siswa di MA Unggulan Mamba'ul Huda Krasak Tegalsari Banyuwangi?

3. Adakah pengaruh manajemen kurikulum terhadap prestasi belajar siswa di MA Unggulan Mamba'ul Huda Krasak Tegalsari Banyuwangi?

4. Seberapa besar pengaruh manajemen kurikulum terhadap prestasi belajar siswa di MA Unggulan Mamba’ul Huda Krasak Tegalsari Banyuwangi?

\section{Manfaat Penelitian}

1. Teoristis

Secara teoristis hasil penelitian diharapkan dapat bermanfaat yaitu :

Memerikan sumbangan pemikiran bagi pengembangan kurikulum di lembaga yang terus berkembang sesuai dengan tuntutan masyarakat dan sesuai kebutuhan peserta didik dan Sebagai referensi pada penelitian-penelitian selanjutnya yang berhubungan dengan manajemen kurikulum dalam meningkatkan prestasi belajar siswa.

2. Praktis

Secara praktis penelitian ini dapat bermanfaat sebagai berkut :

Bagi lembaga pendidikan hasil penelitian ini diharapkan dapat memberi masukan bagi pembaca maupun kepala sekolah dan guru dalam meningkatkan hasil atau prestasi siswa dalam proses belajar mengajar dalam lembaga pendidikan. Bagi 
JMPID ( Jurnal Manajemen Pendidikan Islam Darussalam )

Jurnal Manajemen Pendidikan Islam

Volume: 2, No: 2, September 2020

ISSN : 2722-7146 (online)

peneliti agar mendapat pengalaman dan wawasan, untuk bekal yang akan datang dalam menunjukan mutu pendidikan. Bagi lembaga yang diteliti dapat dijadikan masukan dan perbaikan dalam pengadaan sarana dan prasarana di lemaga pendidikan.

\section{Tinjauan Pustaka}

\section{Landasan Teori}

a. Pengertian Manajemen Kurikulum

Manajemen Kurikulum terdiri dari dua kata dan merupakan dua konsep yang memiliki arti berbeda yang dipadu menjadi satu kalimat. Yang sampai saat ini digunakan sebagai teori untuk memahami pengelolaan kurikulum. Kata manajemen tidak asing lagi bagi kita, sebab manajemen sudah diaplikasikan dalam segala aspek kehidupan, termasuk pendidikan. Manajemen merupakan disiplin ilmu yang mengalami perkembangan sangat cepat, baik teori maupun praktisnya, hal ini dapat dilihat dari lahirnya para penulis dengan karyakarya mukhtahirnya dan terbitnya karya ilmiah para tokoh akademis. (Rusman, 2009:3) Secara etimologi kata manajemen berasal dari bahasa latin, yaitu dari asal kata manus yang berarti tangan dan agree yang berarti melakukan. kata-kata itu digabung menjadi kata kerja managere yang artinya menangani. Managere diterjemahkan ke dalam Bahasa Inggris dalam bentuk kata kerja to manage, dengan kata benda management diterjemahkan ke dalam Bahasa Indonesia menjadi manajemen atau pengelolaan. (Henry L., 2010:10)

Kurikulum adalah seperangkat rencana dan pengaturan mengenai tujuan, isi, dan bahan pelajaran serta cara yang digunakan sebagai pedoman penyelenggaraan kegiatan pembelajaran untuk mencapai tujuan pendidikan tertentu (Pasal 1 Butir 19 UU No. 20 Tahun 2003 tentang Sistem Pendidikan Nasional). Menurut Abuddin Nata (2010:121) kurikulum adalah rencana atau bahasan pengajaran, sehingga arah kegiatan pendidikan menjadi jelas dan terang. Kurikulum adalah rencana tertulis tentang kemampuan yang harus dimiliki berdasarkan standar nasional, materi yang perlu dipelajari dan pengalaman belajar yang harus dijalani untuk mencapai kemampuan tersebut, dan evaluasi yang perlu dilakukan untuk menentukan tingkat pencapaian kemampuan peserta didik, serta seperangkat peraturan yang berkenaan dengan pengalaman belajar peserta didik dalam mengembangkan potensi dirinya pada satuan Pengaruh Manajemen Kurikulum terhadap Prestasi Belajar Siswa Kelas XI IPA di MA Unggulan Mamba'ul Huda Krasak Tegalsari Banyuwangi

Sumari Mawardi, M. Zainul Ihsan Mustofa 
JMPID ( Jurnal Manajemen Pendidikan Islam Darussalam )

Jurnal Manajemen Pendidikan Islam

Volume: 2, No: 2, September 2020

ISSN : 2722-7146 (online)

pendidikan tertentu. Dalam sistem pendidikan nasional, dinyatakan bahwa kurikulum adalah seperangkat rencana dan pengaturan mengenai isi dan lahan pelajaran serta cara yang digunakan sebagai pedoman penyelenggaraan kegiatan belajar mengajar.

Dari kedua konsep teori di atas maka manajemen kurikulum lahir menjadi teori yang baru, manajemen kurikulum ialah sebagai suatu sistem pengelolaan kurikulum yang kooperatif, komprehenshif, sistemik, dalam rangka mewujudkan ketercapaian tujuan kurikulum. Otonomi yang diberikan pada lembaga pendidikan atau sekolah dalam mengelola kurikulum secara mandiri dengan memprioritaskan kebutuhan dan ketercapaian sasaran dalam visi dan misi lembaga pendidikan atau sekolah tidak mengabaikan kebijakan pemerintah yang telah ditetapkan.

Dari beberapa pengertian diatas maka dapat disimpulkan manajemen kurikulum adalah segenap proses usaha bersama untuk memperlancar pencapaian tujuan pembelajaran dengan dititik beratkan pada usaha meningkatkan kualitas interaksi belajar mengajar. Manajemen Kurikulum menekankan pada suatu sistem kurikulum yang berorientasi pada produktivitas, dimana kurikulum tersebut beriorientasi pada peserta didik, kurikulum dibuat agar dapat membuat peserta didik dapat mencapai tujuan hasil belajar.

b. Ruang Lingkup Manajemen Kurikulum

Manajemen kurikulum meliputi perencanaan, pengorganisasian, pelaksanaan, evaluasi kurikulum. Pada dasarnya karakteristik manajemen kurikulum dapat dilihat berdasarkan lingkup yang terbatas pada pelaksanaan kurikulum di suatu sekolah dimulai dari perencanaan, pengorganisasian, pelaksanaan, dan evaluasi kurikulum. Karakteristik manajemen kurikulum adalah sebagai berikut :

1) Perencanaan Kurikulum

Dalam hal perencanaan kurikulum terdiri atas: pengertian perencanaan kurikulum, fungsi, model perencanaan kurikulum, dan desain kurikulum.

2) Pengorganisasian Kurikulum

Pengorganisasian adalah suatu desain bahan kurikulum yang bertujuan untuk memberikan kemudahan kepada siswa dalam proses belajar mengajar sehingga dapat mencapai tujuan pembelajaran secara efektif.

3) Pelaksanaan Kurikulum

Pengaruh Manajemen Kurikulum terhadap Prestasi Belajar Siswa Kelas XI IPA di MA Unggulan Mamba'ul Huda Krasak Tegalsari Banyuwangi

Sumari Mawardi, M. Zainul Ihsan Mustofa 
JMPID ( Jurnal Manajemen Pendidikan Islam Darussalam )

Jurnal Manajemen Pendidikan Islam

Volume: 2, No: 2, September 2020

ISSN : 2722-7146 (online)

Pelaksanaan kurikulum adalah suatu proses penerapan ide, konsep, kebijakan, atau inovasi dalam suatu tindakan praktis sehingga memberikan dampak baik berupa perubahan pengetahuan, keterampilan, nilai, dan sikap (Wahyudin, 2014:26).

4) Evaluasi kurikulum

Evaluasi adalah proses untuk menilai kinerja pelaksanaan suatu kurikulum yang didalamnya memiliki tiga makna, yaitu: (1) evaluasi tidak akan terjadi kecuali sudah mengetahui tujuan yang akan dicapai; (2) untuk mencapai tujuan tersebut harus diperiksa hal-hal yang telah dan sedang dilaksanakan; dan (3) evaluasi harus mengambil kesimpulan berdasarkan pada kriteria tertentu.

c. Landasan Teori Prestasi Belajar Siswa

Prestasi Belajar tidak dapat dipisahkan dari kegiatan belajar, karena belajar merupakan suatu proses, sedangkan prestasi belajar adalah hasil dari proses pembelajaran tersebut. Bagi seorang anak belajar merupakan suatu kewajiban. Berhasil atau tidaknya seorang anak dalam pendidikan tergantung pada proses belajar yang dialami oleh anak tersebut (Cece Wijaya, 2004:27).

Kata prestasi berasal dari bahasa Belanda "Prestasic" yang berarti hasil usaha. Dalam kamus besar Bahasa Indonesia prestasi belajar didefinisikan sebagai hasil penilaian yang diperoleh dari kegiatan persekolahan yang bersifat kognitif dan biasanya ditentukan melalui pengukuran dan penilaian (Hadari Nawawi, 2008:100).

Prestasi belajar siswa didefinisikan sebagai berikut (Tulus Tu'u, 2004:75):

1) Prestasi belajar siswa adalah hasil belajar siswa yang dicapai siswa mengikuti dan mengerjakan tugas dan kegiatan pembelajaran di sekolah.

2) Prestasi belajar siswa tersebut terutama nilai aspek kognitifnya karena bersangkutan dengan kemampuan siswa dalam pengetahuan atau ingatan, pemahaman, aplikasi, analisis, sintesa dan evaluasi.

3) Prestasi belajar siswa dibuktikan dan ditunjukan melalui nilai atau angka nilai dari hasil evaluasi yang dilakukan oleh guru terhadap tugas siswa dan ulangan atau ujian yang ditempuhnya.

Dapat disimpulkan dari urian-urian diatas prestasi belajar adalah kegitan hasil belajar yang bersangkutan dengan kemampuan, pengetahuan, pemahaman siswa dalam 
JMPID ( Jurnal Manajemen Pendidikan Islam Darussalam )

Jurnal Manajemen Pendidikan Islam

Volume: 2, No: 2, September 2020

kegiatan pembelajaran di sekolah. Prestasi belajar dapat ditunjukkan dengan penilaian ranah kognitif, ranah afektif, dan ranah psikomotorik.

a. Ranah Kognitif

Ranah kognitif berkaitan dengan hasil belajar berupa pengetahuan, kemampuan dan kemahiran intelektual (Chatarina Tri Anni, 2004: 6).

b. Ranah Afektif

Ranah afektif berorientasi pada nilai dan sikap, membagi taksonomi ranah afektif menjadi lima kategori yaitu: 1) Penerimaan,2) Penanggapan,3) Penghargaan terhadap nilai,4) Pengorganisasian,5) pembentukan pola hidup (Chatarina Tri Anni, 2004: 8).

c. Ranah Psikomotorik

Ranah psikomotorik menunjukan adanya kemampuan fisik seperti keterampilan motorik dan syaraf, manipulasi objek, dan koordinasi syaraf (Chatarina Tri Anni, 2004: 10).

\section{Kajian Terdahulu}

Dari penelitian yang akan dilakukan, peneliti merujuk dari beberapa penelitian yang hampir sama dengan judul penelitian ini yaitu:

1. Skripsi saudara Ardi Apriliadi, Universitas Pendidikan Indonesia dengan judul "Pengaruh Manajemen Kelas terhadap Prestasi Belajar Siswa pada Mata Pelajaran Produktif Administrasi Perkantoran Kelas X di SMK N 3 Bandung”. Hasil dari penelitian tersebut adalah manajemen kelas di kelas X SMK N 3 Bandung berjalan secara efektif, prestasi belajar siswa di kelas $\mathrm{X}$ masih rendah, dan manajemen kelas memiliki pengaruh positif dan signifikan terhadap prestasi belajar siswa. Artinya manajemen kelas memberikan pengaruh aktif terhadap prestasi belajar siswa di kelas X SMKN 3 Bandung.

2. Skripsi saudari Yuliani Setiyawati, Progam Studi Pendidikan Akuntansi Fakultas Keguruan dan Ilmu Pemerintahan Universitas Muhammadiyah Surakarta dengan judul "Prestasi Belajar Mata Pelajaran Ekonomi Kelas Unggulan Ditinjau dari Aspek Pemilihan, Motivasi Belajar dan Sarana Penunjang Pembelajaran". Hasil dari penelitian di atas adalah adanya pengaruh dari pemilihan kelas unggulan dan non unggulan, motivasi belajar dan pemanfaatan sarana penunjang pembelajaran terhadap prestasi belajar siswa. 
JMPID ( Jurnal Manajemen Pendidikan Islam Darussalam )

Jurnal Manajemen Pendidikan Islam

Volume: 2, No: 2, September 2020

ISSN : 2722-7146 (online)

3. Skripsi saudari Ni Kadek Sukiati Arini, Universitas Gunadarma Depok dengan judul "Pengaruh Tingkat Intelegensi dan Motivasi Belajar terhadap Prestasi Akademik Siswa Kelas II SMA Negeri 99 Jakarta”. Hasil dari penelitian ini adalah adanya pengaruh secara signifikan dari tingkat intelegensi dan motivasi belajar baik secara parsial maupun bersama terhadap prestasi akademik.

Dari ketiga penelitian ini, penelitian (a) meneliti tentang adanya pengaruh dari motivasi belajar dan pemanfaatan sarana penunjang pembelajaranterhadap prestasi belajar siswa, (b) adanya pengaruh secara signifikan dari tingkat intelegensi dan motivasi belajar baik secara parsial maupun bersama terhadap prestasi akademik, (c) manajemen kelas memberikan pengaruh aktif terhadap prestasi belajar siswa.

Persamaan penelitian ini dengan penelitian terdahulu adalah sama sama menggunakan variabel tentang prestasi belajar siswa tetapi yang membedakan adalah variabel yang lain dimana penelitian (a) tentang motivasi dan sarana belajar, penelitian (b) tingkat intelegensi dan motivasi, penelitian (c) tentang manajemen kelas dan penelitian. Sedangkan pada penelitian ini memilih judul pengaruh manajemen kurikulum terhadap prestasi belajar siswa dan yang membedakan adalah pada penelitian ini fokus tertuju pada manajemen kurikulum yang mempengaruhi prestasi belajar siswa dengan subjek siswa kelan XI di MA Unggulan Mamba’ul Huda.

\section{E. Metode Penelitian}

1. Jenis Penelitan

Jenis penelitian ini merupakan penelitian deskriftif kuantitatif, karena penelitian deskriptif adalah penelitian memiliki tujuan untuk memperoleh deskripsi tentang ciri-ciri variabel penelitian. Karena data yang diperoleh dari data sempel populasi penelitian dianalisis sesuai dengan metode statistik yang digunakan kemudian diinterprestasikan (Sugiyono 2003:14).

2. Lokasi penelitian

Lokasi atau tempat penelitian adalah lokasi tertentu yang digunakan untuk objek dan subjek yang akan di teliti dalam penelitian. Penelitian dilaksanakan di MA Unggulan Mamba'ul huda Krasak Tegalsari Banyuwangi.

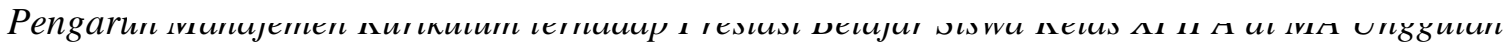
Mamba'ul Huda Krasak Tegalsari Banyuwangi

Sumari Mawardi, M. Zainul Ihsan Mustofa 
JMPID ( Jurnal Manajemen Pendidikan Islam Darussalam )

Jurnal Manajemen Pendidikan Islam

Volume: 2, No: 2, September 2020

3. Sumber Data

Pengumpulan data dalam penelitian ini menggunakan metode- metode yang disesuaikan dengan masalah yangakan diteliti atau dianalisa. Dalam penelitiaan kali ini diunakan beberapa metode pengumpulan data yaitu metode observasi, angket, dokumentasi dan interview (Sugiyono, 2013:145).

4. Teknik Pengumpulan Data

Karena data yang digunakan berupa data primer dan data sekunder maka teknik yang digunakan dalam pengumpulan data pada penitian ini adalah :

a. Observasi

Observasi dilakukan untuk mengamati keadaan yang ada di MA Unggulan Mamba'ul Huda Krasak Tegalsari Banyuwangi baik itu berupa keadaan sekolah, lingkungan ataupun kegiatan yang ada. Juga digunakan cara untuk mendapatkan data sekolah seperti data kurikulum dan siswa berprestasi.

b. Kuesioner (angket)

Kuesioner atau angket biasanya dilakukan secara tertulis, angket ini penulis gunakan sebagai alat untuk memperoleh data yang diambil dari pertanyaan atau pernyataan yang ditujukan kepada responden.

c. Dokumentasi

Dokumentasi ini dilakukan untuk mendapatkan data berupa gambar sekolah, prestasi siswa, serta daftar-daftar harian yang mungkin penulis butuhkan.

d. Metode interview

Interview merupakan proses tanya jawab dalam penelitian yang berlangsung secara lisan dengan dua orang atau lebih, bertatap muka dengan mendengarkan secara langsung informasi-informasi atau keterangan - keterangan (Arikunto, $2006: 133)$.

\section{Analisis Data}

Penelitian ini adalah penelitian untuk mengetahui ada atau tidaknya pengaruh antara dua variabel dan seberapa besar pengaruh tersebut, maka penulis menggunakan analisis korelasi product moment, dengan rumus :

$$
r_{x y}=\frac{N \sum X Y\left(\sum Y\right)\left(\sum Y\right)}{\sqrt{\left\{N \sum X^{2}-\left(\sum X\right)^{2}\right\}\left\{N \sum Y^{2}-\left(\sum Y\right)^{2}\right\}}}
$$

Pengaruh Manajemen Kurikulum terhadap Prestasi Belajar Siswa Kelas XI IPA di MA Unggulan Mamba'ul Huda Krasak Tegalsari Banyuwangi

Sumari Mawardi, M. Zainul Ihsan Mustofa 
JMPID ( Jurnal Manajemen Pendidikan Islam Darussalam )

Jurnal Manajemen Pendidikan Islam

Volume: 2, No: 2, September 2020

ISSN : 2722-7146 (online)

Keterangan

$r_{x y}:$ koefisien validitas

$N$ : banyaknya subjek

$x \quad$ : Nilai pembanding

$Y$ : Nilai dari instrument yang akan dicari validitasnya

Seperti yang dikatakan Sugiyono (2015:56) untuk hipotesis asosiatif bila data kedua variabel berbentuk internal atau rasio, maka menggunakan teknik statistik korelasi product moment. dalam perhitungan ini peneliti menggunakan program SPSS.

\section{F. Hasil Penelitian}

\section{Analisis Data Variabel $X$}

Langkah-langkah membuat tabel interpretasi analisis manual analisis kualiatif.

Nilai rata-rata variabel $\mathrm{X}=36,54$

Nilai tertinggi angket $=12 \times 4=48$

Nilai terendah angket $=12 \times 1=12$

Selisih nilai $\quad=48-12=36$

Banyak kategori $(\mathrm{I}=$ Interval) $=5$ (sangat baik, baik, sedang, kurang, sangat kurang).

Isi kelas (i) interval $\quad=\quad \frac{X_{t}-X_{t}}{i}=\frac{48-12}{5}=\frac{36}{5}=7,2$

Tabel F 1 Interprestasi Hasil Angket

\begin{tabular}{|c|c|}
\hline Interval & Kategori \\
\hline $40,9-48,0$ & Sangat Baik \\
\hline $33,7-40,8$ & Baik \\
\hline $26,5-33,6$ & Sedang \\
\hline $19,2-26,4$ & Kurang \\
\hline $12,0-19,1$ & Sangat Kurang \\
\hline
\end{tabular}

Sumber Data : Hasil Olahan Peneliti, 2020

Pengaruh Manajemen Kurikulum terhadap Prestasi Belajar Siswa Kelas XI IPA di MA Unggulan Mamba'ul Huda Krasak Tegalsari Banyuwangi

Sumari Mawardi, M. Zainul Ihsan Mustofa 
JMPID ( Jurnal Manajemen Pendidikan Islam Darussalam )

Jurnal Manajemen Pendidikan Islam

Volume: 2, No: 2, September 2020

ISSN : 2722-7146 (online)

Dapat di simpukan nilai rata-rata variabel $X \quad($ manajemen kurikulum $)=36,54$ dan terletak pada tabel interprestasi hasil angket antara 33,6 - 40,8 dengan kategori bak, maka manajemen kurikulum di MA Unggulan Mamba'ul huda

\section{Baik.}

\section{Analisis Data Variabel Y}

Nilai rata-rata variabel Y diselisihkan dengan nilai KKM kelas XI IPA

Jika rata-rata variabel Y sama atau lebih dari KKM berkategori Baik

Jika nilai rata-rata variabel Y kurang dari KKM berkategori Kurang.

Tabel F 2 Interprestasi Nilai Prestasi Siswa

\begin{tabular}{|c|c|}
\hline Interval & Kategori \\
\hline $86-100$ & Sangat Baik \\
\hline $76-85$ & Baik \\
\hline $60-75$ & Cukup \\
\hline $40-59$ & Kurang \\
\hline
\end{tabular}

Sumber Data : MA Unggulan Mamba'ul Huda

Dapat di simpukan dari nilai rata-rata kelas variabel $\mathrm{Y}=\mathbf{8 4 , 8 6}$ diselisihkan dengan KKM kelas (dilihat dari tabel interprestasi nilai prestasi siswa) maka prestasi belajar siswa di MA Unggulan Mamba'ul Huda berkategori Baik.

Untuk menyatakan ada atau tidaknya hubungan variabel ( $\mathrm{X}$ ) manajemen kurikulum dan variabel (Y) prestasi belajar siswa.

Tabel Data F 3 Correlations

Correlations

\begin{tabular}{|l|r|r|}
\hline & & \\
& najemen kurikulum & prestasi belajar \\
\hline hajemen kurikulum & 1 &, 770 \\
(2-tailed) & 37 &, 000 \\
& 37 \\
\hline
\end{tabular}

Pengaruh Manajemen Kurikulum terhadap Prestasi Belajar Siswa Kelas XI IPA di MA Unggulan Mamba'ul Huda Krasak Tegalsari Banyuwangi

Sumari Mawardi, M. Zainul Ihsan Mustofa 
JMPID ( Jurnal Manajemen Pendidikan Islam Darussalam )

Jurnal Manajemen Pendidikan Islam

Volume: 2, No: 2, September 2020

ISSN : 2722-7146 (online)

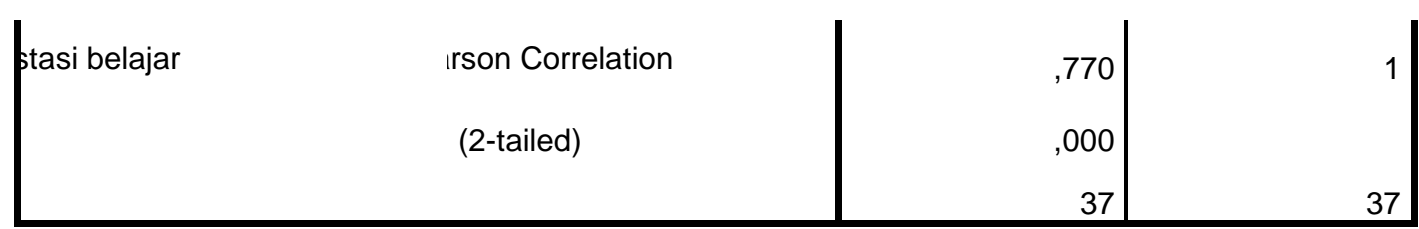

Sumber Data : Hasil Olahan Peneliti, 2020

\section{Interprestasi Output SPSS :}

a. Pada bagian nilai Correlations Sig. (2tailed) menunjukkan 0,00. Jika nilai Sig. (2-tailed) $<0,05$ maka terdapat korelasi antara variabel yang dihubungkan. Sebaliknya jika nilai Sig.(2-tailed) > 0,05 Maka tidak terdapat korelasi. Maka disimpulkan adanya hububungan antara manajemen kurikulum dan prestasi belajar siswa.

b. Pada bagian nilai Pearson Correlation menunjkkan 0,770 yang berarti menunjukkan hubungan positif. Nilai $\mathrm{r}$ terbesar adalah +1 dan $\mathrm{r}$ terkecil $-1=$ +1 menunjukkan hubungan positif sempurna, sedangkan -1 menunjukkan hubungan negatif sempurna. Maka disimpulkan ada pengaruh hubungan yang positif antara manajemen kurikulum dan prestasi belajar siswa.

Besar pengaruh hubungan antara variabel $(\mathrm{X})$ dan variabel $(\mathrm{Y})$ prestasi belajar siswa dengan mengetahui Nilai $r$.

Nilai $r$ terbesar adalah +1 dan $r$ terkecil adalah $-1 . r=+1$ menunjukkan hubungan positif sempurna, sedangkan $r=-1$ menunjukkan hubungan negatif sempurna. interprestasi nilai $\mathrm{r}$ adalah sebagai berikut :

Tabel Data F 4 Derajat Hubungan

\begin{tabular}{|c|l|}
\hline $\mathbf{r}$ & \multicolumn{1}{c|}{ Kategori } \\
\hline 0 & Tidak Berkorelasi \\
\hline $0,01-0,20$ & Korelasi Sangat Lemah \\
\hline $0,21-0,40$ & Lemah \\
\hline $0,41-0,60$ & Cukup \\
\hline $0,61-0,80$ & Kuat \\
\hline $0,81-0,99$ & Sangat Kuat \\
\hline 1 & Korelasi Sempurna \\
\hline
\end{tabular}

Sumber Data: Hasil Olahan Peneliti 
JMPID ( Jurnal Manajemen Pendidikan Islam Darussalam )

Jurnal Manajemen Pendidikan Islam

Volume: 2, No: 2, September 2020

ISSN : 2722-7146 (online)

Berdasarkan hasil ouput pada tabel data F 3 Correlations, nilai Pearson Correlation menunjkkan 0,770 yang mendekati nilai 1 berarti menunjukkan hubungan positif. Maka disimpulkan melihat tabel data F 4 derajat hubungan diatas, besarnya pengaruh hubungan antara variabel $(\mathrm{X})$ manajemen kurikulum dan variabel (Y) prestasi belajar siswa berkatehori kuat.

\section{G. Pembahasan}

1. Manajemen Kurikulum

Permasalahan pertama yang dipertanyakan dalam penelitian adalah bagaimana manajemen kurikulum di MA Unggulan Mamba'ul Huda Krasak Tegalsari Banyuwangi Tahun Akademik 2019/2020. Sesuai dengan hasil perhitungan statistik manual diambil dari hasil rata-rata data variabel (X) 36,54 bila dilihat dari tabel data F 1 interprestasi hasil angket menunjukkan bahwa manajemen kurikulum di MA Unggulan Mamba'ul Huda Krasak Tegalsari Banyuwangi tahun akademik 2019/2020 masuk pada kategori baik.

2. Prestasi Belajar Siswa

Permasalahan kedua yang dipertanyakan dalam penelitian ini adalah bagaimana prestasi belajar siswa di MA Unggulan Mamba'ul Huda Krasak Tegalsari Banyuwangi tahun akademik 2019/2020. Sesuai dengan perhitungan statistik manual dilihat dari hasil rata-rata data variabel (Y) 84,86 dlihat tabel data F 2 interprestasi prestasi belajar menunjukkan bahwa prestasi belajar siswa di MA Unggulan Mamba'ul Huda Krasak Tegalsari Banyuwangi tahun akademik 2019/2020 masuk pada kategori baik.

3. Pengaruh Manajemen Kurikulum Terhadap Prestasi Belajar Siswa

Permasalahan ketiga dari penelitian ini adalah adakah pengaruh manajemen kurikulum terhadap prestasi belajar siswa di MA Unggulan Mamba'ul Huda Krasak Tegalsari Banyuwangi tahun akademik 2019/2020. Sesuai hasil penelitian menunjukkan adanya pengaruh atau hubungan antara manajemen kurikulum dan prestasi belajar siswa. Hal tersebut dapat dilihat pada tabel output SPSS pengujian hipotesis analisis product moments yang menunjukan nilai signifikansi $0,00<0,05$ yang berarti terdapat adanya pengaruh signifikansi antara variabel (X) manajemen kurikulum dan variabel (Y) prestasi belajar siswa.

Pengaruh Manajemen Kurikulum terhadap Prestasi Belajar Siswa Kelas XI IPA di MA Unggulan Mamba'ul Huda Krasak Tegalsari Banyuwangi

Sumari Mawardi, M. Zainul Ihsan Mustofa 
JMPID ( Jurnal Manajemen Pendidikan Islam Darussalam )

Jurnal Manajemen Pendidikan Islam

Volume: 2, No: 2, September 2020

4. Besarnya pengaruh manajemen kurikulum terhadap prestasi belajar siswa

Permasalahan keempat adalah seberapa besar pengaruh manajemen kurikulum terhadap prestasi belajar siswa di MA Unggulan Mamba'ul Huda Krasak Tegalsari Banyuwangi tahun akademik 2019/2020. Sesuai hasil penelitian menunjukkan adanya pengaruh yang Kuat antara manajemen kurikulum terhadap prestasi belajar siswa. Besar pengaruh dengan mengetahui nilai $r$. Nilai $r$ terbesar adalah +1 dan $r$ terkecil adalah $-1 . r=+1$ menunjukkan hubungan positif sempurna, sedangkan $r=-1$ menunjukkan hubungan negatif sempurna sesuai hasil dari nilai Pearson Correlation menunjkkan 0,770 yang artinya berkategori kuat (lihat tabel $\mathrm{F}$ 4 derajat hubungan).

\section{H. Kesimpulan}

Berdasarkan hasil penelitian dan analisis data yang sudah diuraikan dapat disimpulkan sebagai berikut :

1. Berdasarkan data hasil perhitungan statistik manual diambil dari hasil rata-rata data variabel (X) 36,54 bila dilihat dari tabel data F 1 interprestasi hasil angket menunjukkan bahwa manajemen kurikulum di MA Unggulan Mamba'ul Huda Krasak Tegalsari Banyuwangi tahun akademik 2019/2020 masuk pada kategori baik.

2. Berdasarkan data perhitungan statistik manual dilihat dari hasil rata-rata data variabel (Y) 84,86 dlihat tabel data F 2 interprestasi prestasi belajar menunjukkan bahwa prestasi belajar siswa di MA Unggulan Mamba'ul Huda Krasak Tegalsari Banyuwangi tahun akademik 2019/2020 masuk pada kategori baik.

3. Berdasarkan hasil uji hipotesis analisis Product Moment Carrelation di ketahui bahwa hasil Sig. (2 tailed) menunjukkan $0,00<0,05$ yang berarti terdapat hubungan yang signifikan antara variabel (X) manajemen kurikulum dengan variabel (Y) prestasi belajar siswa.

4. Berdasarkan hasil uji hipotesis analisis Product Moment Carrelation di ketahui bahwa hasil nilai Pearson Correlation menunjkkan 0,770. Nilai $r$ terbesar adalah +1 dan $\mathrm{r}$ terkecil adalah $-1 . \mathrm{r}=+1$ menunjukkan hubungan positif sempurna, sedangkan $r=-1$ menunjukkan hubungan negatif sempurna sesuai hasil dari nilai 
JMPID ( Jurnal Manajemen Pendidikan Islam Darussalam )

Jurnal Manajemen Pendidikan Islam

Volume: 2, No: 2, September 2020

Pearson Correlation menunjkkan 0,770 yang artinya berkategori kuat (lihat tabel $\mathrm{F}$ 4 derajat hubungan).

\section{Saran}

Berdasarkan hasil penelitian, pembahasan, dan kesimpulan diatas, disampaikan beberapa saran atau rekomendasi sebagai berikut :

1. Bagi Pihak Lembaga

Berdasarkan hasil penelitian pembahasan, dan kesimpulan melihat dari jumlah data angket dan lager nilai rata-rata siswa kls XI IPA mempunyai hubungan yang positif yang dimana semakin baik manajemen kurikulum semakin baik juga prestasi belajar siswa. diharapkan pengelola sekolah mampu meningkatkan manajemen kurikulum yang ada di sekolah mulai tahap perencanaan, pengelolaan, pengorganisasian dan evaluasi kurikulum agar prestasi belajar siswa semakin lebih baik.

2. Bagi Peneliti Selanjutnya

Berdasarkan penelitian, pembahasan, dan kesimpulan yang telah disampaikan bagi peneliti selanjutnya diharapkan lebih banyak menambah refrensi dan mengkaji banyak sumber agar penelitian yang dilakukan lebih maksimal.

\section{J. Daftar Pustaka}

Abuddin, Nata. 2010. Ilmu Pendidikan Islam. Jakarta: Kencana Prenada Media Group. Anni, Catharina Tri, dkk. 2004. Psikologi Belajar. Semarang: UPT UNNES Press.

Arikunto, Suharsimi. 2006. Metode Penelitian Kualitatif. Jakarta: Bumi Aksara.

Arikunto, Suharsimi. 2010. Prosedur Penelitian (suatu pendekatan praktik). Jakarta: PT Rineka Cipta.

Budi, Triton, P. 2006. SPSS Terapan Riset Statistik Parametik. Yogyakarta: CV. Andi Offset.

Cece, Wijaya. 2004. Kemampuan Guru Dalam Proses Belajar Mengajar. Bandung: PT Remaja Rosdakarya.

Dalton, Maurice. 2012. Community Psychology Individual And Communities 3rd Edition, USA: Wadsworth Cengage Learning. 
JMPID ( Jurnal Manajemen Pendidikan Islam Darussalam )

Jurnal Manajemen Pendidikan Islam

Volume: 2, No: 2, September 2020

Hadari, Nawawi. 2008. Metode Penelitian Bidang Sosial. Yogyakarta: Gadjah Mada University Press.

Hamalik, Oemar 2003. Perencanaan Pengajaran Berdasarkan Pendekatan Sistem. Bumi Aksara.

Henry, L. Sisk. 2010. Principles Of Management, Cicago: Soutth Western Publishing Company.

Manab, Abdul. 2014. Manajemen Perubahan Kurikulum Mendesain Pembelajaran. Yogyakarta: Kalimedia.

Mulyasa, 2015. Pengembangan Dan Implementasi Kurikulum 2013. Bandung: PT Remaja Rosdakarya Offset.

Rusman. 2009. Manajemen Kurikulum. Jakara: Raja Grafindo Persada.Saefullah. Saefullah, U. 2014. Manajemen Pendidikan Islam. Bandung: CV Pustaka Setia.

Sugiyono, 2015. Metode Penelitian Kombinasi (Mix Methods). Bandung: Alfabeta

Sugiyono, 2017. Metode Penelitian Pendidikan Pendekatan Kuantitatif, Kualitatif, dan $R \& D$. Bandung: Alfabeta.

Syah, Muhibbin. 2008. Psikologi Belajar. Jakarta: PT Raja Grafindo Persada.

Tim Penyusun Pedoman Penulisan Skripsi, 2020. Pedoman Penulisan Skripsi, Blokagung: IAIDA Blokagung.

Tulus, Tu'u. 2004. Peran Disiplin Pada Prilaku dan Prestasi Siswa. Jakarta: Rineka Cipta.

Undang-Undang Reepublik Indonesia Nomor 20 Tahun 2003 Tentang Sistem Pendidikan Nasional. 2005. Jakarta : PT. Armas Duta Jaya.

Wahyudin, 2014. Manajemen Kurikulum. Bandung: PT Remaja Rosdakarya Offset. 